\title{
Production and Consumption of Biodiesel and Ethanol: A Comparison, from 2000 to 2010
}

\author{
Roberto Guimarães Pereira ${ }^{1}$ and Valdir de Jesus Lameira ${ }^{2}$ \\ 1. Fluminense Federal University, TEM/PGMEC/MSG/PGEB, Rua Passo da Pátria 156, CEP 24210-240, Niterói-RJ, Brazil \\ 2. Researcher at Energy Economics,INESC Coimbra, Rua Antero de Quental, 199, Coimbra 3000-033, Portugal
}

Received: May 10, 2013 / Accepted: June 16, 2013 / Published: October 25, 2013.

\begin{abstract}
The present work, an investigation concerning the biofuels production and consumption, from 2000 to 2010, of different regions: Asia and Oceania; Central and South America; European Union and North America. The Brazilian case is also studied. In all regions studied, the production and consumption grows significantly in this period. The production is local and adapts to agricultural inputs available for production, being an activity related to regional development. It is also observed that Europe has greater production and consumption of biodiesel, while Brazil and the U.S. have higher production and consumption of ethanol. It is also presented the top 5 countries in the world in biodiesel and ethanol production and consumption, from 2000 to 2010. Furthermore, biofuels increased their relevance in energy matrices around the world.
\end{abstract}

Key words: Biofuels, biodiesel, ethanol, production, consumption.

\section{Introduction}

The renewable energies play an important role in sustainability. The use of biofuels in energy generation contributes to sustainable development in view of its environmental, energetic and social-economic benefits.

Some reasons for sufficiently strengthening the program for the use of biofuels are: the variation in prices for oil, which in recent years has fluctuated between $\$ 40$ and 150 per barrel, the political and social pressure in order to reduce the emission of gases that cause global warming, the development of the market for carbon credits, and the possibility of strengthening the energy matrix, reducing dependence on foreign energy sources and giving relief to the trade balance with clear effects on the macroeconomics of the country.

Biodiesel and ethanol are biofuels used in the world with success, in substitution to diesel and gasoline. In general, biofuels increased their percentage share in

Corresponding author: Roberto Guimarães Pereira, D.Sc., research fields: renewable energy, biofuel and rheology. E-mail: temrobe@vm.uff.br. total fuel available for consumption. Moreover, the biofuels have special features such as production near the consumption and utilization of available inputs and adapted to production regions.

This paper analyses the evolution of production and consumption of biofuels (biodiesel and ethanol) from 2000 to 2012 in different regions: Asia and Oceania; Central and South America; European Union and North America. The Brazilian case is also studied. It is also presented the top 5 countries in the world in biodiesel and ethanol production and consumption, from 2000 to 2010.

\subsection{Biodiesel}

The possibility to produce hydrocarbons from different raw material to replace the diesel makes the definition of biodiesel a complex and legal nature. Many documents of academic nature define biodiesel as a monoalkyl ester of vegetable oil or animal fat, but official documents and international standards are more specific, defining the process by which one can 
obtain the ester and the characteristics that it must have to be considered biodiesel.

The regulations for biodiesel have been developed in different countries where its use is permitted. In U.S., the standard for biodiesel is set by the technical standard ASTM D 6751, in the European Union, it is related with the standard EN 14214 and in Brazil it is set in the National Petroleum Agency (ANP) resolution No. 14 from 11.05.2012.

The use of biodiesel as fuel in partial or total replacement to diesel has many advantages that have been highlighted in Refs. [1-4]. The advantages in environmental, energetic and social-economic aspects can be seen below.

Environmental advantages of biodiesel are: greenhouse gas reductions; biodegradability; higher combustion efficiency; carbon sequestration; lower sulfur content; lower aromatic content; less toxicity.

Energetic advantages of biodiesel are: supply reliability; higher flash point; reducing use of fossil fuels; ready availability; renewability.

Social-economic advantages of biodiesel are: sustainability; fuel diversity; increased income taxes; increased investments in plant and equipment; international competitiveness; reducing the dependency on imported petroleum.

In Brazil, there are currently 69 biodiesel plants authorized by ANP to operate in the country, representing a total authorized capacity of 22,244.06 $\mathrm{m}^{3}$ per day. Among these 69 plants, 64 have market authorization of biodiesel produced, corresponding to 20,393.04 $\mathrm{m}^{3}$ per day capacity authorized for marketing [5].

There are also 3 new biodiesel plants approved for construction and 11 plants of biodiesel allowed to expand capacity. With the completion of works and subsequent authorization for operation, the total authorized capacity can be increased by $2,064.72 \mathrm{~m}^{3}$ per day [5].

Among the raw materials used to produce biodiesel in Brazil, we highlight the soybean oil (78.43\%), the beef tallow (18.97\%) and the frying oil (1.17\%). The Brazilian biodiesel production in 2012 reached $265,3840 \mathrm{~m}^{3}$. Since January 2010, all diesel sold in Brazil has contained 5\% biodiesel [5].

\subsection{Ethanol}

Ethanol is one of the most important renewable fuels contributing to the reduction of negative environmental impacts generated by the worldwide utilization of fossil fuels. Sugar cane is the most important feedstock utilized in tropical and sub-tropical countries (including Brazil) for producing ethanol. In European countries, beet molasses are the most utilized, while in the USA corn is used [6].

Ethanol can be used net or blended with gasoline to improve vehicle performance and reduce air pollution.

The cars driving in Brazil using two types of fuel ethanol: hydrous consumed in engines designed for this purpose, and the anhydrous, which is mixed with gasoline, without harm to motors in varying proportions. Since July 2007, all gasoline sold in Brazil has contained 25\% anhydrous ethanol fuel [7].

The Brazilian ethanol production in 2011-2012 harvest year was 22,705,697 $\mathrm{m}^{3}$, being 14,082,083 $\mathrm{m}^{3}$ of hydrous ethanol and $8,623,614 \mathrm{~m}^{3}$ of anhydrous ethanol [8].

\section{Methodology}

This research has an exploratory nature. The aim is the investigation of the evolution of production and consumption of biofuels (biodiesel and ethanol) in different regions: Asia and Oceania; Central and South America; European Union and North America, from 2000 to 2010. The Brazilian case is also studied. In this research a central question is whether the production has characteristics linked to regional development or whether there are large generators and consumers involving multilateral trades. It is also presented the top 5 countries in the world in biodiesel and ethanol production and consumption, from 2000 to 2010. This kind of research aims to show the evolution of biofuels 
usage in the world from the period of 2000 to 2010.

The data were obtained from the U.S. Energy Information Administration site [9], from the period of 2000 to 2010.

\section{Results and Discussion}

Fig. 1 shows the total biofuels production from 2000 to 2010. As we can see in all regions studied, the production grows significantly. In 2000, the highest production occurred in the Central and South American region (185.13 thousand barrels per day). In 2010, the highest production occurred in the North American region (914.42 thousand barrels per day). In Brazil, the biofuels production increased $186.7 \%$, from 183.89 to 527.32 thousand barrels per day, in the period from 2000 to 2010. In the Euro region (EU-27), the biofuels production increased $1357.1 \%$, from 17.10 to 249.16 thousand barrels per day, in the period from 2000 to 2010. In 2010, the Brazilian biofuels production represented $28.5 \%$ of the global production while the Euro region was $13.5 \%$.

In 2000, the biodiesel (Fig. 2) was produced only in the Euro region (15.10 thousand barrels per day) and in the Central and South American region (0.10 thousand barrels per day). In 2010, the highest production occurred in the Euro region (183.76 thousand barrels per day). In Brazil, the biodiesel production in 2005 was 0.01 thousand barrels per day, reaching 41.12 thousand barrels per day in 2010. In 2010, the Brazilian biodiesel production represented $12.4 \%$ of global production while the Euro region was 55.2\%.

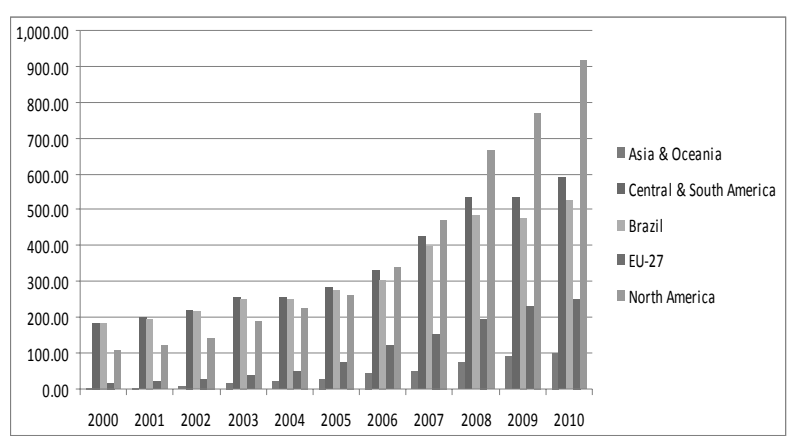

Fig. 1 Total biofuels production (thousand barrels per day) from 2000 to 2010.

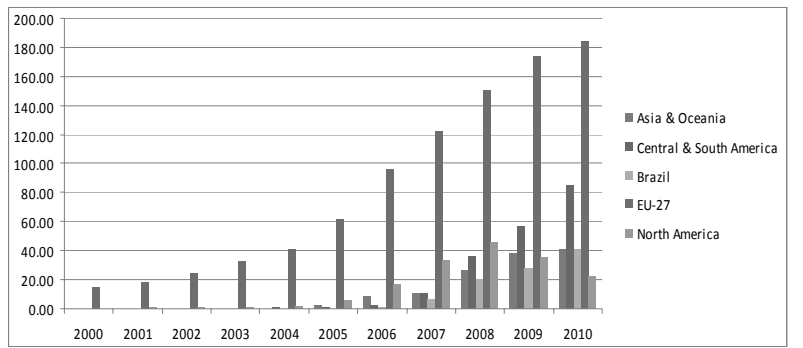

Fig. 2 Biodiesel production (thousand barrels per day) from 2000 to 2010.

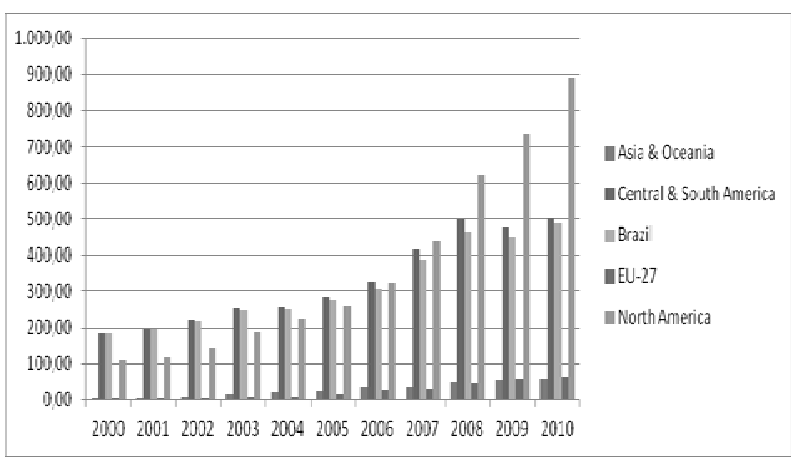

Fig. 3 Ethanol production (thousand barrels per day) from 2000 to 2010.

Table 1 shows the top 5 countries in biodiesel production from 2000 to 2010.

Fig. 3 shows the total ethanol production from 2000 to 2010. In 2000, the highest production occurred in the Central and South American region (185.03 thousand barrels per day). In 2010, the highest production occurred in the North American region (891.74 thousand barrels per day). In Brazil, the ethanol production increased $164.3 \%$ from 183.89 to 486.01 thousand barrels per day, in the period from 2000 to 2010. In the Euro region (EU-27), the ethanol production increased $3170 \%$, from 2 to 65.4 thousand barrels per day, in the period of 2000 to 2010. In 2010, the Brazilian ethanol production represented $32 \%$ of global production while the Euro region was $4.3 \%$.

Table 2 shows the top 5 countries in ethanol production from 2000 to 2010.

The total biofuels consumption, from 2000 to 2010, is shown in Fig. 4. The highest consumption, in 2000, occurred in the Central and South American region (168.09 thousand barrels per day). In 2010, the highest 
Table 1 Top 5 countries-biodiesel production (thousands barrels per day) from 2000 to 2010.

\begin{tabular}{|c|c|c|c|c|c|c|c|c|c|c|c|}
\hline & 2000 & 2001 & 2002 & 2003 & 2004 & 2005 & 2006 & 2007 & 2008 & 2009 & 2010 \\
\hline 1 & $\begin{array}{l}\text { France } \\
(5.9)\end{array}$ & $\begin{array}{l}\text { France } \\
\text { (5.9) }\end{array}$ & $\begin{array}{l}\text { Germany } \\
\text { (8.8) }\end{array}$ & $\begin{array}{l}\text { Germany } \\
\text { (14) }\end{array}$ & $\begin{array}{l}\text { Germany } \\
\text { (20) }\end{array}$ & $\begin{array}{l}\text { Germany } \\
\text { (33) }\end{array}$ & $\begin{array}{l}\text { Germany } \\
\text { (52) }\end{array}$ & $\begin{array}{l}\text { Germany } \\
\text { (57) }\end{array}$ & $\begin{array}{l}\text { Germany } \\
\text { (55) }\end{array}$ & $\begin{array}{l}\text { Germany } \\
\text { (45) }\end{array}$ & $\begin{array}{l}\text { Germany } \\
\text { (49) }\end{array}$ \\
\hline 2 & $\begin{array}{l}\text { Germany } \\
\text { (4.3) }\end{array}$ & $\begin{array}{l}\text { Germany } \\
(5.4)\end{array}$ & $\begin{array}{l}\text { France } \\
(6.4)\end{array}$ & $\begin{array}{l}\text { France } \\
(7.3)\end{array}$ & $\begin{array}{l}\text { France } \\
(7.7)\end{array}$ & $\begin{array}{l}\text { France } \\
(8.4)\end{array}$ & $\begin{array}{l}\text { United } \\
\text { States } \\
(16.3)\end{array}$ & $\begin{array}{l}\text { United } \\
\text { States } \\
\text { (31.9) }\end{array}$ & $\begin{array}{l}\text { United } \\
\text { States } \\
(44.1)\end{array}$ & $\begin{array}{l}\text { France } \\
\text { (41) }\end{array}$ & $\begin{array}{l}\text { Brazil } \\
(41.1)\end{array}$ \\
\hline 3 & Italy (1.6) & Italy (2.8) & Italy (4.1) & Italy (5.3) & Italy (6.2) & Italy (7.7) & $\begin{array}{l}\text { France } \\
\text { (11.6) }\end{array}$ & $\begin{array}{l}\text { France } \\
\text { (18.7) }\end{array}$ & $\begin{array}{l}\text { France } \\
\text { (34.4) }\end{array}$ & $\begin{array}{l}\text { United } \\
\text { States } \\
\text { (33.6) }\end{array}$ & $\begin{array}{l}\text { France } \\
\text { (37) }\end{array}$ \\
\hline 4 & Spain (1.6) & Spain (1.6) & $\begin{array}{l}\text { Czech } \\
\text { Republic } \\
\text { (2) }\end{array}$ & $\begin{array}{l}\text { Czech } \\
\text { Republic } \\
(2.2)\end{array}$ & Spain (2.2) & $\begin{array}{l}\text { United } \\
\text { States } \\
(5.9)\end{array}$ & $\begin{array}{l}\text { Italy } \\
(11.6)\end{array}$ & Italy (9.2) & $\begin{array}{l}\text { Brazil } \\
(20.0)\end{array}$ & $\begin{array}{l}\text { Brazil } \\
(27.7)\end{array}$ & $\begin{array}{l}\text { Argentina } \\
\text { (36) }\end{array}$ \\
\hline 5 & $\begin{array}{l}\text { Czech } \\
\text { Republic } \\
(1.3)\end{array}$ & $\begin{array}{l}\text { Czech } \\
\text { Republic } \\
(1.4)\end{array}$ & Spain (1.5) & Spain (2) & $\begin{array}{l}\text { United } \\
\text { States } \\
(1.8)\end{array}$ & Spain (3.2) & $\begin{array}{l}\text { Austria } \\
(2.4)\end{array}$ & $\begin{array}{l}\text { Brazil } \\
(6.9)\end{array}$ & $\begin{array}{l}\text { Argentina } \\
\text { (13.9) }\end{array}$ & $\begin{array}{l}\text { Argentina } \\
(23.1)\end{array}$ & $\begin{array}{l}\text { United } \\
\text { States } \\
(22.4)\end{array}$ \\
\hline
\end{tabular}

Table 2 Top 5 countries-ethanol production (thousands barrels per day) from 2000 to 2010.

\begin{tabular}{|c|c|c|c|c|c|c|c|c|c|c|c|}
\hline & 2000 & 2001 & 2002 & 2003 & 2004 & 2005 & 2006 & 2007 & 2008 & 2009 & 2010 \\
\hline 1 & $\begin{array}{l}\text { Brazil } \\
(183.8)\end{array}$ & $\begin{array}{l}\text { Brazil } \\
(197.5)\end{array}$ & $\begin{array}{l}\text { Brazil } \\
(216.9)\end{array}$ & $\begin{array}{l}\text { Brazil } \\
(249.3)\end{array}$ & $\begin{array}{l}\text { Brazil } \\
(251.7)\end{array}$ & $\begin{array}{l}\text { Brazil } \\
(276.4)\end{array}$ & $\begin{array}{l}\text { United } \\
\text { States } \\
(318.6)\end{array}$ & $\begin{array}{l}\text { United } \\
\text { States } \\
\text { (425.3) }\end{array}$ & $\begin{array}{l}\text { United } \\
\text { States } \\
\text { (605.5) }\end{array}$ & $\begin{array}{l}\text { United } \\
\text { States } \\
\text { (713.4) }\end{array}$ & $\begin{array}{l}\text { United } \\
\text { States } \\
\text { (867.4) }\end{array}$ \\
\hline 2 & $\begin{array}{l}\text { United } \\
\text { States } \\
(105.5)\end{array}$ & $\begin{array}{l}\text { United } \\
\text { States } \\
(115.1)\end{array}$ & $\begin{array}{l}\text { United } \\
\text { States } \\
(139.6)\end{array}$ & $\begin{array}{l}\text { United } \\
\text { States } \\
\text { (182.9) }\end{array}$ & $\begin{array}{l}\text { United } \\
\text { States } \\
(221.4)\end{array}$ & $\begin{array}{l}\text { United } \\
\text { States } \\
(254.6)\end{array}$ & $\begin{array}{l}\text { Brazil } \\
(306.1)\end{array}$ & $\begin{array}{l}\text { Brazil } \\
(388.7)\end{array}$ & $\begin{array}{l}\text { Brazil } \\
(466.2)\end{array}$ & $\begin{array}{l}\text { Brazil } \\
(449.8)\end{array}$ & $\begin{array}{l}\text { Brazil } \\
(486)\end{array}$ \\
\hline 3 & India (2.9) & India (3) & China (5) & $\begin{array}{l}\text { China } \\
\text { (13.8) }\end{array}$ & $\begin{array}{l}\text { China } \\
(17.2)\end{array}$ & $\begin{array}{l}\text { China } \\
\text { (20.7) }\end{array}$ & China (28) & $\begin{array}{l}\text { China } \\
\text { (28.7) }\end{array}$ & $\begin{array}{l}\text { China } \\
(34.4)\end{array}$ & China (37) & China \\
\hline 4 & France (2) & France (2) & India (3.2) & India (3.3) & Spain (4) & Spaiı & $\begin{array}{l}\text { Germany } \\
(7.4)\end{array}$ & $\begin{array}{l}\text { France } \\
(9.3)\end{array}$ & $\begin{array}{l}\text { France } \\
\text { (16) }\end{array}$ & $\begin{array}{l}\text { France } \\
\text { (17) }\end{array}$ & $\begin{array}{l}\text { France } \\
\text { (18) }\end{array}$ \\
\hline 5 & Cuba (1.1) & Cuba (1) & France (2) & Spain (3) & India (3.5) & India (3.7) & Spain (7) & Spain (7) & $\begin{array}{l}\text { Germany } \\
(10)\end{array}$ & $\begin{array}{l}\text { Germany } \\
\text { (13) }\end{array}$ & $\begin{array}{l}\text { Germany } \\
\text { (13) }\end{array}$ \\
\hline
\end{tabular}

consumption occurred in the North American region (888.30 thousand barrels per day). In Brazil, the biofuels consumption increased $154.3 \%$ from 166.85 to 424.34 thousand barrels per day, in the period of 2000 to 2010. In Euro region (EU-27), the biofuels consumption increased $1901.6 \%$, from 16.30 to 326.27 thousand barrels per day, in the period of 2000 to 2010 . The Brazilian biofuels consumption, in 2010, represented $24.1 \%$ of global production, while the Euro region was $18.5 \%$.

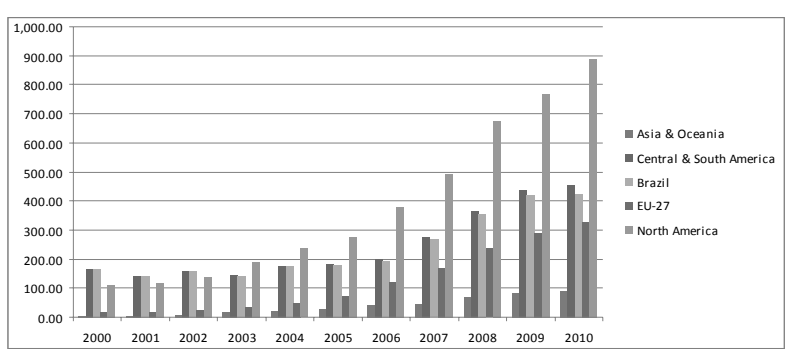

Fig. 4 Total biofuels consumption (thousand barrels per day) from 2000 to 2010.
The biodiesel consumption (Fig. 5), in 2000, occurred only in the Euro region (14.30 thousand barrels per day) and in the Central and South American region ( 0.10 thousand barrels per day). The highest consumption, in 2010, occurred in the Euro region (229.35 thousand barrels per day). In Brazil, the biodiesel consumption in 2005 was 0.06 thousand barrels per day, reaching 42.43 thousand barrels per day in 2010. The Brazilian biodiesel consumption in 2010 represented $12.3 \%$ of global consumption, while the Euro region was $66.6 \%$.

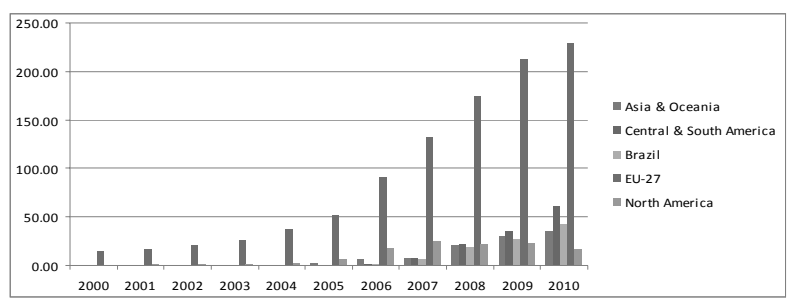

Fig. 5 Biodiesel consumption (thousand barrels per day) from 2000 to 2010. 
Table 3 Top 5 countries biodiesel consumption (thousands barrels per day) from 2000 to 2010.

\begin{tabular}{|c|c|c|c|c|c|c|c|c|c|c|c|}
\hline & 2000 & 2001 & 2002 & 2003 & 2004 & 2005 & 2006 & 2007 & 2008 & 2009 & 2010 \\
\hline 1 & $\begin{array}{l}\text { France } \\
\text { (6) }\end{array}$ & $\begin{array}{l}\text { Germany } \\
(6.8)\end{array}$ & $\begin{array}{l}\text { Germany } \\
(10.8)\end{array}$ & $\begin{array}{l}\text { Germany } \\
(15.7)\end{array}$ & $\begin{array}{l}\text { Germany } \\
(20.5)\end{array}$ & $\begin{array}{l}\text { Germany } \\
\text { (35) }\end{array}$ & $\begin{array}{l}\text { Germany } \\
\text { (56) }\end{array}$ & $\begin{array}{l}\text { Germany } \\
\text { (64) }\end{array}$ & $\begin{array}{l}\text { Germany } \\
\text { (53) }\end{array}$ & $\begin{array}{l}\text { Germany } \\
\text { (49) }\end{array}$ & $\begin{array}{l}\text { Germany } \\
\text { (50.5) }\end{array}$ \\
\hline 2 & $\begin{array}{l}\text { Germany } \\
\text { (4.9) }\end{array}$ & $\begin{array}{l}\text { France } \\
(6.0)\end{array}$ & $\begin{array}{l}\text { France } \\
(6.3)\end{array}$ & $\begin{array}{l}\text { France } \\
(5.9)\end{array}$ & $\begin{array}{l}\text { France } \\
(6.4)\end{array}$ & $\begin{array}{l}\text { France } \\
(7.1)\end{array}$ & $\begin{array}{l}\text { United } \\
\text { States } \\
\text { (16.9) }\end{array}$ & $\begin{array}{l}\text { France } \\
(25.3)\end{array}$ & $\begin{array}{l}\text { France } \\
(40.6)\end{array}$ & $\begin{array}{l}\text { France } \\
\text { (45) }\end{array}$ & $\begin{array}{l}\text { Brazil } \\
(42.4)\end{array}$ \\
\hline 3 & Spain (1.6) & Spain (1.6) & Spain (1.5) & Spain (2) & Italy (5.6) & $\begin{array}{l}\text { United } \\
\text { States } \\
(5.9)\end{array}$ & $\begin{array}{l}\text { France } \\
(13.5)\end{array}$ & $\begin{array}{l}\text { United } \\
\text { States } \\
(23.3)\end{array}$ & $\begin{array}{l}\text { United } \\
\text { States } \\
(20.5)\end{array}$ & $\begin{array}{l}\text { Brazil } \\
(26.9)\end{array}$ & $\begin{array}{l}\text { France } \\
(40)\end{array}$ \\
\hline 4 & $\begin{array}{l}\text { Czech } \\
\text { Republic } \\
\text { (1.4) }\end{array}$ & $\begin{array}{l}\text { Czech } \\
\text { Republic } \\
\text { (1) }\end{array}$ & $\begin{array}{l}\text { Czech } \\
\text { Republic } \\
\text { (1.4) }\end{array}$ & $\begin{array}{l}\text { Czech } \\
\text { Republic } \\
\text { (1.4) }\end{array}$ & Spain (2.2) & Italy (3.9) & $\begin{array}{l}\text { Austria } \\
(6.4)\end{array}$ & $\begin{array}{l}\text { Austria } \\
(7.2)\end{array}$ & $\begin{array}{l}\text { Brazil } \\
(19.1)\end{array}$ & $\begin{array}{l}\text { Italy } \\
\text { (23.3) }\end{array}$ & Italy (30) \\
\hline 5 & $\begin{array}{l}\text { Austria } \\
(0.4)\end{array}$ & $\begin{array}{l}\text { United } \\
\text { States } \\
(0.6) \\
\end{array}$ & $\begin{array}{l}\text { United } \\
\text { States } \\
(1.0) \\
\end{array}$ & $\begin{array}{l}\text { United } \\
\text { States } \\
(0.8) \\
\end{array}$ & $\begin{array}{l}\text { United } \\
\text { States } \\
(1.7) \\
\end{array}$ & Spain (3.2) & Italy (4.4) & $\begin{array}{l}\text { Brazil } \\
(6.3)\end{array}$ & $\begin{array}{l}\text { United } \\
\text { Kingdom } \\
(15.3)\end{array}$ & $\begin{array}{l}\text { United } \\
\text { States } \\
(21.2) \\
\end{array}$ & Spain (26) \\
\hline
\end{tabular}

Table 4 Top 5 countries-ethanol consumption (thousands barrels per day) from 2000 to 2010.

\begin{tabular}{|c|c|c|c|c|c|c|c|c|c|c|c|}
\hline & 2000 & 2001 & 2002 & 2003 & 2004 & 2005 & 2006 & 2007 & 2008 & 2009 & 2010 \\
\hline 1 & $\begin{array}{l}\text { Brazil } \\
(166.8)\end{array}$ & $\begin{array}{l}\text { Brazil } \\
(141.3)\end{array}$ & $\begin{array}{l}\text { Brazil } \\
(160.1)\end{array}$ & $\begin{array}{l}\text { United } \\
\text { States } \\
(184.3)\end{array}$ & $\begin{array}{l}\text { United } \\
\text { States } \\
(231)\end{array}$ & $\begin{array}{l}\text { United } \\
\text { States } \\
(264.7)\end{array}$ & $\begin{array}{l}\text { United } \\
\text { States } \\
(357.5)\end{array}$ & $\begin{array}{l}\text { United } \\
\text { States } \\
(449.1)\end{array}$ & $\begin{array}{l}\text { United } \\
\text { States } \\
(629.9)\end{array}$ & $\begin{array}{l}\text { United } \\
\text { States } \\
\text { (719.9) }\end{array}$ & $\begin{array}{l}\text { United } \\
\text { States } \\
(838.7)\end{array}$ \\
\hline 2 & $\begin{array}{l}\text { United } \\
\text { States } \\
(107.5)\end{array}$ & $\begin{array}{l}\text { United } \\
\text { States } \\
\text { (113.5) }\end{array}$ & $\begin{array}{l}\text { United } \\
\text { States } \\
(135.2)\end{array}$ & $\begin{array}{l}\text { Brazil } \\
(144)\end{array}$ & $\begin{array}{l}\text { Brazil } \\
(177.1)\end{array}$ & $\begin{array}{l}\text { Brazil } \\
(181.8\end{array}$ & $\begin{array}{l}\text { Brazil } \\
(194.1)\end{array}$ & $\begin{array}{l}\text { Brazil } \\
(262)\end{array}$ & $\begin{array}{l}\text { Brazil } \\
(336.5)\end{array}$ & $\begin{array}{l}\text { Brazil } \\
(393.2)\end{array}$ & $\begin{array}{l}\text { Brazil } \\
(381.9)\end{array}$ \\
\hline 3 & India (2.9) & India (3) & China (5) & $\begin{array}{l}\text { China } \\
(13.8)\end{array}$ & $\begin{array}{l}\text { China } \\
(17.2)\end{array}$ & $\begin{array}{l}\text { China } \\
\text { (20.7) }\end{array}$ & China (28) & $\begin{array}{l}\text { China } \\
\text { (28.7) }\end{array}$ & $\begin{array}{l}\text { China } \\
\text { (34.4) }\end{array}$ & China (37) & China (37) \\
\hline 4 & France (2) & $\begin{array}{l}\text { France } \\
(1.8)\end{array}$ & India (3.2) & India (3.3) & Swedan(4) & $\begin{array}{l}\text { Germany } \\
\text { (5.7) }\end{array}$ & $\begin{array}{l}\text { Germany } \\
\text { (11) }\end{array}$ & $\begin{array}{l}\text { Germany } \\
\text { (10) }\end{array}$ & $\begin{array}{l}\text { France } \\
\text { (14) }\end{array}$ & $\begin{array}{l}\text { Germany } \\
\text { (19) }\end{array}$ & $\begin{array}{l}\text { Germany } \\
\text { (25) }\end{array}$ \\
\hline 5 & Cuba (1.1) & Cuba (1) & France (2) & Spain (3) & India (3.5) & $\begin{array}{l}\text { Swedan } \\
(4.3)\end{array}$ & $\begin{array}{l}\text { Swedan } \\
\text { (5.5) }\end{array}$ & France (5) & $\begin{array}{l}\text { Germany } \\
\text { (13) }\end{array}$ & $\begin{array}{l}\text { France } \\
\text { (14) }\end{array}$ & $\begin{array}{l}\text { France } \\
\text { (15) }\end{array}$ \\
\hline
\end{tabular}

Table 3 shows the top 5 countries in biodiesel consumption from 2000 to 2010.

Fig. 6 shows the total ethanol consumption from 2000 to 2010. The highest consumption, in 2000, occurred in the Central and South American region (165.85 thousand barrels per day). In 2010, the highest consumption occurred in the North American region (871.08 thousand barrels per day). In Brazil, the ethanol consumption increased $128.9 \%$, from 166.85 to 381.91 thousand barrels per day, in the period of 2000

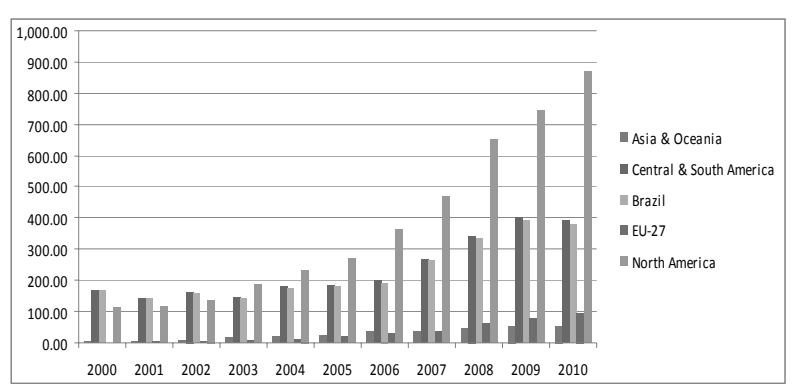

Fig. 6 Ethanol consumption (thousand barrels per day) from 2000 to 2010. to 2010. In the Euro region (EU-27), the ethanol consumption increased $47.46 \%$, from 2 to 96.92 thousand barrels per day, in the period from 2000 to 2010. The Brazilian ethanol consumption, in 2010, represented $26.9 \%$ of global production, while the Euro region was $6.8 \%$.

Table 4 shows the top 5 countries in ethanol consumption from 2000 to 2010.

\section{Conclusions}

Energy demand has grown significantly at the end of the first decade of this century as a result of a very large growth of the global economy. It seems reasonable to say that the growth of energy demand was so high that it would be difficult to meet this demand, as shown in Figs. 1-4.

Looking at the numbers, it is observed that Europe has greater production and consumption of biodiesel, while Brazil and the U.S. have higher production and 
consumption of ethanol. It is also possible to observe that there were no large gaps between production and consumption of biofuels, which demonstrates that the production is close to where this fuel will be consumed.

It is possible to conclude that the increasing quest for clean energy and the increase of knowledge and development of new and more efficient technologies encourage the production and consumption of biofuels as an important source of energy to compose an increasingly important part of the energy supply from our societies around the world.

Analyzing the data of production and consumption it can be concluded that the tendency for the future is a situation close to balance between them. Still one can conclude that the production fits local farming availabilities.

In the case of Brazil, where soybean oil represents $78.43 \%$ of the raw material used to produce biodiesel, it is recommended to enhance the contribution of other raw materials (beef tallow, chicken tallow, pig tallow, cottonseed oil, palm oil, sunflower oil, peanut oil etc) in view of the great diversity of oilseeds and animals tallow in Brazil. Furthermore, it is very important to enhance the participation of family farming in the vegetable oil production, reaching the social aspect of the Biodiesel National Program.

Concerning the production and use of ethanol, it is worthwhile to emphasize the success of the Brazilian Program, contributing to the reduction of negative environmental impacts generated by the use of fossil fuels. In fact, in Brazil great part of the cars are flex being possible to use ethanol, gasoline and blends of ethanol and gasoline as fuel. Also, the gasoline sold in Brazil contains 25\% anhydrous ethanol.

In a general view, an increase in the production and use of biofuels (ethanol and biodiesel) is observed in the world leading to a more sustainable development.

\section{Acknowledgments}

The author Roberto G. Pereira is grateful to the National Research Council of Brazil-CNPq for the financial support.

This work has been partially supported by the Portuguese Foundation for Science and Technology under project grant[s] PEst-OE/ EEI/UI308/2014. The author Valdir de Jesus Lameira is also grateful to European Social Fund.

\section{References}

[1] A. Demirbas, Biofuels securing the planet's future energy needs, Energy Conversion and Management 50 (9) (2009) 2239-2249.

[2] R.G. Pereira, C.D. Oliveira, J.L. Oliveira, P.C.P. Oliveira, C.E. Fellows, O.E. Piamba, Exhaust emissions and electric energy generation in a stationary engine using blends of diesel and soybean biodiesel, Renewable Energy 32 (14) (2007) 2453-2460.

[3] R.G. Pereira, O.E.P. Tulcan, V.J. Lameira, D.M.E. Santo Filho, E.T. Andrade, Use of soybean oil in energy generation, Recent trends for enhancing the diversity and quality of soybean products, Tech. Publishing, Rijeka, Croatia, 2011, pp. 301-320.

[4] R.G. Pereira, O.E.P. Tulcan, C.E. Fellows, V.J. Lameira, O.L.G. Quelhas, M.E. Aguiar, et al., Sustainability and mitigation of greenhouse gases using ethyl beef tallow biodiesel in energy generation, Journal of Cleaner Production 29-30 (2012) 269-276.

[5] ANP, Monthly Bulletin of Biodiesel, June 2013, National Agency of Petroleum, Natural Gas and Biofuels (in Portuguese), www.anp.gov.br/?id=472 (accessed 27.08.13).

[6] C.A. Cardona, O.J. Sánchez, Fuel ethanol production: Process design trends and integration opportunities, Bioresource Technology 98 (2007) 2415-2457.

[7] ANP, 2013, National Agency of Petroleum, Natural Gas and Biofuels, http://www.anp.gov.br/?pg=57994\&m $=\& \mathrm{t} 1=\& \mathrm{t} 2=\& \mathrm{t} 3=\& \mathrm{t} 4=\& \mathrm{ar}=\& \mathrm{ps}=\& \mathrm{cach}$ ebust $=137771350$ 5507 (accessed 27.08.13). (in Portuguese)

[8] MAPA, 2012, Ministry of Agriculture, Livestock and Supply, available at http://www.agricultura.gov.br/ arq_editor/file/Desenvolvimento_Sustentavel/Agroenergi a/estatisticas/producao/AGOSTO_2012/06_\%20prod_eta nol_tipo.pdf (accessed 16.09.12). (in Portuguese)

[9] EIA, U.S. Energy Information Administration available at www.eia.gov/contries/data/cfm, (accessed 09.08.13). 